Kiyoshi Kanno • Yoichi Suzuki • Xuemei Yang

Atsushi Yamada • Yoko Aoki • Shigeo Kure

Yoichi Matsubara

\title{
Lack of evidence for a significant association between nonsyndromic cleft lip with or without cleft palate and the retinoic acid receptor alpha gene in the Japanese population
}

Received: January 15, 2002 / Accepted: February 25, 2002

\begin{abstract}
Nonsyndromic cleft lip with or without cleft palate (NSCLP) is one of the most common craniofacial malformations. Both genetic and environmental factors are thought to be involved in the pathogenesis. The retinoic acid receptor $\alpha(R A R A)$ is one of the candidate genes for the pathogenesis of NSCLP. An association between a Pst I restriction fragment length polymorphism or D17S579 microsatellite marker polymorphism of the RARA gene and NSCLP was previously suggested, but no nucleotide change that may influence the gene expression or the protein sequence has been reported to date. To investigate the possible association between the RARA gene and NSCLP in Japanese patients, we performed a transmission disequilibrium test (TDT) using three microsatellite markers at the $R A R A$ locus in 48 parent-offspring trios. The allele-wise TDT did not show evidence of an association between the RARA gene and NSCLP. We also screened nucleotide changes in eight patients with family histories using exonby-exon direct sequencing. We found a novel nucleotide change $(1161 \mathrm{C}>\mathrm{T})$ that is located in exon 1 of the $R A R A$ gene in one patient whose father also had the disease. Because the $1161 \mathrm{C}>\mathrm{T}$ was inherited from the patient's healthy mother, the mutation was not considered to be responsible for NSCLP. We then screened all probands for the nucleotide changes in the promoter region of the RARA gene using denaturing high-performance liquid chromatography. A novel nucleotide length polymorphism of a thymidine tract was identified in three patients. No association between this polymorphism and NSCLP was observed. Our findings suggest that the RARA gene variations do not contribute to the development of NSCLP in the Japanese population.
\end{abstract}

K. Kanno · Y. Suzuki $(\triangle) \cdot$ Y. Aoki $\cdot$ S. Kure · Y. Matsubara Department of Medical Genetics, Tohoku University School of Medicine, 1-1 Seiryomachi, Aoba-ku, Sendai 980-8574, Japan Tel. +81-22-717-8140; Fax +81-22-717-8142

e-mail: ysuzuki@mail.cc.tohoku.ac.jp

K. Kanno $\cdot$ X. Yang $\cdot$ A. Yamada

Department of Plastic Surgery, Tohoku University School of

Medicine, Sendai, Japan
Key words Nonsyndromic cleft lip with or without cleft palate $\cdot$ Retinoic acid $\cdot$ Retinoic acid receptor alpha $\cdot$ Transmission disequilibrium test - Denaturing high-performance liquid chromatography · Polymorphism · Microsatellite marker

\section{Introduction}

Nonsyndromic cleft lip with or without cleft palate (NSCLP [MIM 119530]) is one of the most common congenital anomalies, with an incidence of 1/700 to 1/1000 live births. Both environmental and genetic factors are thought to be involved in its pathogenesis. Although some of the familial cases are known to show a Mendelian pattern of inheritance, the majority seems to be inherited in a complex manner (Wyszynski et al. 1996). It is well established that an excess of retinoic acid (RA), a natural derivative of vitamin $\mathrm{A}$, is teratogenic for the palate and other organs (Geelen 1979). The expression of a dominant negative mutation of RA receptor cDNA promoted craniofacial defects qualitatively similar to the teratogenic effects of RA administration (Damm et al. 1993). RA acts by interacting with retinoic receptor $\alpha(R A R A)$ and retinoid $\mathrm{X}$ receptor, from which arose the hypothesis that variations at the $R A R A$ locus affect the susceptibility to NSCLP. Chenevix-Trench et al. (1992) first suggested an association between NSCLP and Pst I restriction fragment length polymorphism (RFLP) in the RARA gene in a Caucasian population. Using a microsatellite marker, D17S579, an association was also demonstrated in an Indian population (Shaw et al. 1993). On the other hand, Vintiner et al. (1993) failed to show an association between the Pst I polymorphism and the disease in British patients. No evidence of a linkage of the $R A R A$ gene to the disease was obtained in two other studies (Shaw et al. 1993; Vintiner et al. 1993). However, parametric linkage analysis may not be an appropriate approach for investigating susceptible genes of genetically complex diseases. Therefore, we cannot exclude the RARA gene as a candidate gene for NSCLP on the basis of these studies. 
In the present study we examined whether the $R A R A$ gene is involved in the pathogenesis of NSCLP by different analytical approaches in a Japanese population. First, a transmission disequilibrium test (TDT) of three multialleic markers adjacent to the $R A R A$ gene was performed. We also screened mutation/polymorphism of the gene in patients with family histories and in patients who had alleles for which transmission disequilibrium was suspected by the TDT. Finally, using denaturing high-performance liquid chromatography (DHPLC), we screened the nucleotide changes in the promoter region of the $R A R A$ gene.

\section{Patients and methods}

Patients

Forty-eight Japanese NSCLP probands and their parents were recruited for this study. Written and oral informed consent was obtained from all subjects. This study was approved by the Ethics Committee of Tohoku University School of Medicine. A family history was obtained from each participant to determine the presence of related individuals with NSCLP and other anomalies. Blood samples were collected from the probands and their parents.

\section{DNA analysis}

DNA was prepared from whole blood samples using a GFR DNA purification kit (Amersham Pharmacia Biotech,
Buckinghamshire, England). Thyroid hormone receptor $\alpha$ (THRA1), D17S579, and D17S800 were chosen as markers for the $R A R A$ gene. The $R A R A$ gene was mapped to chromosome $17 \mathrm{q} 12-\mathrm{q} 21$, which spans $40 \mathrm{~kb}$ of genomic DNA. THRA1 was located about $250 \mathrm{~kb}$ centromeric to the $R A R A$ gene. D17S579 and D17S800 were about $4.55 \mathrm{Mb}$ and $470 \mathrm{~kb}$ telomeric to the gene, respectively. Genomic DNA was amplified by polymerase chain reaction (PCR) using as primers the following pairs (forward and reverse): for THRA1, 5'-CTGCGCTTTGCACTATTGGG-3' and 5'-CGGGCAGCATAGCATTGCCT-3'; for D17S579, 5' AGTCCTGTAGACAAAACCTG-3' and 5'-CAGTTTC ATACCAAGTTCCT-3'; and for D17S800, 5'-GGTCTC ATCCATCAGGTTTT-3' and 5'-ATAGACTGTGTACT GGGCATTGA-3'. All forward primers were FAM (6carboxy-fluorescein)-labeled at their $5^{\prime}$ ends. Twenty microliters of reaction mixture contained $20 \mathrm{ng}$ of genomic DNA, $10 \mathrm{mM}$ Tris/ $\mathrm{HCl}$ ( $\mathrm{pH} 8.3), 50 \mathrm{mM} \mathrm{KCl}, 1.5 \mathrm{mM} \mathrm{MgCl}_{2}$, $250 \mu \mathrm{M}$ of each deoxyribonucleosidetriphosphate (dNTP), $6 \mu \mathrm{M}$ of each primer, and 1 unit of Taq polymerase (Takara, Kyoto, Japan). The amplification conditions were $94^{\circ} \mathrm{C}$ for $12 \mathrm{~min}$, followed by 25 cycles of $94^{\circ} \mathrm{C}$ for $20 \mathrm{~s}, 55^{\circ} \mathrm{C}$ for $30 \mathrm{~s}$, and $72^{\circ} \mathrm{C}$ for $1 \mathrm{~min}$, and ending with a single 10 -min extension step at $72^{\circ} \mathrm{C}$. The length of the PCR product was analyzed using an ABI 373XL DNA Sequencer (Applied Biosystems, Forester, MA, USA).

Eight probands with other affected member(s) in the family were subjected to exon-by-exon mutation screening of the $R A R A$ gene. Exons 1 to 9 of the $R A R A$ gene were amplified by PCR using 13 pairs of primers shown in Table 1. Thirty microliters of reaction mixture contained $10 \mathrm{ng}$ of

Table 1. Primer sequences for amplifying exons in the $R A R A$ gene and conditions for denaturing high-performance liquid chromatography (DHPLC)

\begin{tabular}{|c|c|c|c|c|}
\hline Primer & Primer sequence & Fragment & $\begin{array}{l}\text { Product size } \\
\text { (bp) }\end{array}$ & $\begin{array}{l}\text { DHPLC running } \\
\text { temperature }\left({ }^{\circ} \mathrm{C}\right)\end{array}$ \\
\hline Exon1-1F & 5'-ТСТTCTCCACCGAGCGCTATT-3' & E1F1 & 331 & 616263 \\
\hline Exon1-1R & 5'-TCACGTGCGGAGGCTGAAACT-3' & & & \\
\hline Exon1-2F & 5'-GCGGGCGTGAGCCTGTAGATC-3' & E1F2 & 397 & 636465 \\
\hline Exon1-2R & 5'-CACCAATCTGGGGCAGGACAT-3' & & & \\
\hline Exon2-1F & 5'-CCTGTGTGCCTGTTCTTCAGT-3' & $\mathrm{E} 2 \mathrm{~F} 1$ & 387 & 606162 \\
\hline Exon2-1R & 5'-CAGACAGTCTGGCAGGGGGCT-3' & & & \\
\hline Exon2-2F & 5'-СССАААССССАТСТGGGCCCA-3' & E2E2 & 380 & 626364 \\
\hline Exon2-2R & 5'-ACTCACAGCAGAACAGACGTG-3' & & & \\
\hline Exon3F & 5'-TGGAGCTTGGTACTAAGGATG-3' & E3 & 290 & 596061 \\
\hline Exon3R & 5'-ACACTCCCAGGACACAGAAGT-3' & & & \\
\hline Exon4F & 5'-TCCCTAGACTGAGACCGTAGC-3' & E4 & 316 & 606162 \\
\hline Exon4R & 5'-GTGCACAAACATCCACAGAGC-3' & & & \\
\hline Exon5F & 5'-TGGCAGCTCTCTGTCAGGCTG-3' & E5 & 340 & 616263 \\
\hline Exon5R & 5'-GATCTTGCCTGGCACAAGAAG-3' & & & \\
\hline Exon6F & 5'-TGAAGGCTGGGTAGAGGGCAG-3' & E6 & 368 & 616263 \\
\hline Exon6R & 5'-TTGCAGACAGACATTTAGGAG-3' & & & \\
\hline Exon7F & 5'-ATCAGACAGCATTGCTCCGGC-3' & E7 & 433 & 626364 \\
\hline Exon7R & 5'-CTAGAGATACCTAACAGAGGT-3' & & & \\
\hline Exon8F & 5'-TGGGGAGGCGCCTGCGAGCTG-3' & E8 & 352 & 626364 \\
\hline Exon8R & 5'-ATGGGGTGCTGGCTTGGATGT-3' & & & \\
\hline Exon9-1F & 5'-AGTATTGATCTTCCCACCTCG-3' & E9F1 & 414 & 616263 \\
\hline Exon9-1R & 5'-AGGGCAGGTGGGGGCAGGGCT-3' & & & \\
\hline Exon9-2F & 5'-СTTTCTACCGACCATGTGACC-3' & E9F2 & 270 & 626364 \\
\hline Exon9-2R & 5'-GATGTGGTGAGCTGGGCAGAG-3' & & & \\
\hline Exon9-3F & 5'-GGCCTCGTGTTCATCAAGACA-3' & E9F3 & 323 & 626364 \\
\hline Exon9-3R & 5'-CAATACACAGCACAAATTCCT-3' & & & \\
\hline
\end{tabular}


genomic DNA, $10 \mathrm{mM}$ Tris $/ \mathrm{HCl}(\mathrm{pH} 8.3), 50 \mathrm{mM} \mathrm{KCl}$, $1.5 \mathrm{mM} \mathrm{MgCl} 2,250 \mu \mathrm{M}$ each dNTP, $6 \mu \mathrm{M}$ each primer, and 1.5 unit of Taq polymerase. The amplification cycles of E1F1, E1F2, E2F1, E2F2, E3, E4, E5, E6, E7, and E9F3 were $94^{\circ} \mathrm{C}$ for $1 \mathrm{~min}$, followed by 35 cycles of $94^{\circ} \mathrm{C}$ for $30 \mathrm{~s}$, $55^{\circ} \mathrm{C}$ for $40 \mathrm{~s}$, and $72^{\circ} \mathrm{C}$ for $1 \mathrm{~min}$, and ending with a single 10 -min extension step at $75^{\circ} \mathrm{C}$. The conditions of $\mathrm{E} 8$ were $94^{\circ} \mathrm{C}$ for $3 \mathrm{~min}$, followed by 35 cycles of $94^{\circ} \mathrm{C}$ for $30 \mathrm{~s}, 60^{\circ} \mathrm{C}$ for $30 \mathrm{~s}$, and $68^{\circ} \mathrm{C}$ for $40 \mathrm{~s}$, and ending with a single 10-min extension step at $72^{\circ} \mathrm{C}$. The conditions of $\mathrm{E} 9 \mathrm{~F} 1$ and $\mathrm{E} 9 \mathrm{~F} 2$ were $94^{\circ} \mathrm{C}$ for $1 \mathrm{~min}$, followed by 35 cycles of $94^{\circ} \mathrm{C}$ for $30 \mathrm{~s}$, $60^{\circ} \mathrm{C}$ for $40 \mathrm{~s}$, and $72^{\circ} \mathrm{C}$ for $50 \mathrm{~s}$, and ending with a single 10 min extension step at $72^{\circ} \mathrm{C}$.

Direct sequencing of the PCR products was performed using the dideoxy chain-termination method. Reaction samples were analyzed with an ALF express II according to the manufacturer's protocol (Amersham Pharmacia Biotech).

Nucleotide changes in the region up to $-965 \mathrm{bp}$ of the translation initiation site of the RARA gene (nucleotide number is according to the accession number AF088888) were screened by heteroduplex analysis using DHPLC. This region includes the whole promoter sequence characterized in the previous report (Brand et al. 1990). The DNA was amplified by PCR using primers shown in Table 2 . Thirty microliters of reaction mixture contained $10 \mathrm{ng}$ of genomic DNA, $10 \mathrm{mM}$ of Tris/ $\mathrm{HCl}(\mathrm{pH} 8.3), 50 \mathrm{mM}$ of $\mathrm{KCl}, 1.5 \mathrm{mM}$ of $\mathrm{MgCl}_{2}, 250 \mu \mathrm{M}$ of each dNTP, $6 \mu \mathrm{M}$ each primer, and 1.5 units Taq polymerase. The amplification conditions of fragments PRO1, PRO2, PRO4, and PRO5 were $94^{\circ} \mathrm{C}$ for $1 \mathrm{~min}$, followed by 40 cycles of $94^{\circ} \mathrm{C}$ for $30 \mathrm{~s}, 55^{\circ} \mathrm{C}$ for $40 \mathrm{~s}$, and $72^{\circ} \mathrm{C}$ for $50 \mathrm{~s}$, and ending with a single 10 -min extension step at $75^{\circ} \mathrm{C}$. The conditions of PRO3 were $94^{\circ} \mathrm{C}$ for $1 \mathrm{~min}$, followed by 40 cycles of $94^{\circ} \mathrm{C}$ for $30 \mathrm{~s}, 58^{\circ} \mathrm{C}$ for $40 \mathrm{~s}$, and $72^{\circ} \mathrm{C}$ for $50 \mathrm{~s}$, and ending with a single 10 -min extension step at $75^{\circ} \mathrm{C}$. Finally, each PCR product was denatured at $94^{\circ} \mathrm{C}$ for $5 \mathrm{~min}$ and gradually cooled to $4^{\circ} \mathrm{C}$. The running temperatures of the chromatography for the PCR products are shown in Table 2. Three microliters of each mixed PCR product was applied to the column and the absorbance at $280 \mathrm{~nm}$ of the eluent was monitored on a DNA Screen System (Shimazu Corporation, Kyoto, Japan).

In 11 probands who had a 175-bp allele of THRA1 and/ or a 121-bp allele of D17S579, nucleotide changes in exons
1 to 9 of the RARA gene were screened by the DHPLC method. PCR conditions were the same as the protocol used in the direct sequencing. The running temperatures are shown in Table 1 . When aberrant peak profiles were detected in DHPLC, the PCR products were used as templates for direct sequencing by a fluorescent dye-terminator cycle sequencing method (ABI PRISM Big Dye Terminator Cycle Sequencing Ready Reaction kit, Applied Biosystems).

\section{Statistical methods}

The TDT for multialleic markers was performed using the extended TDT (ETDT) program (URL: http:// www.gene.ucl.ac.uk/users/dcurtis/software.html) (Zhao et al. 1999; Sham and Curtis 1995). The MCETDT program was used to obtain empirical $P$ values for the allele-wise and genotype-wise TDT. The association study was carried out using SPSS for Windows version 10.0J. Significance was set at a $P$ value of 0.05 .

\section{Results}

Among 48 probands, 40 had cleft lip with cleft palate and 8 had cleft lip only. Positive family histories were observed in 10 families. There were 3 probands who had an affected sibling, and 4 probands who had an affected parent. No birth defects other than NSCLP were recorded in any families enrolled in this study. There were no histories of exposure to possible mutagens.

Genotyping of microsatellite markers (THRA1, D17S579, and D17S800) was performed in all probands and their parents (48 probands and 96 parents). THRA1, 17S579, and D17S800 showed 11, 10, and 6 different alleles in size, respectively, among these family members. The ETDT and MCETDT were used as a test for the deviation of transmission of multiple alleles from heterozygous patients to their affected offspring. The results of genotypewise TDT and allele-wise TDT of the three markers are shown in Table 3. The calculated $P$ value for D17S579 in the genotype-wise TDT was less than 0.05 , whereas the empiri-

Table 2. Primer sequences for amplifying the promoter region in the $R A R A$ gene and conditions for denaturing high-performance liquid chromatography (DHPLC)

\begin{tabular}{|c|c|c|c|c|}
\hline Primer & Sequence & Fragment & $\begin{array}{l}\text { Product size } \\
\text { (bp) }\end{array}$ & $\begin{array}{l}\text { DHPLC running } \\
\text { temperature }\left({ }^{\circ} \mathrm{C}\right)\end{array}$ \\
\hline Promotor1F & 5'-GGAGTATTCTAAGCAATTCTGCTT-3' & PRO1 & 285 & 585960 \\
\hline Promotor1R & 5'-CAAGACTTTTGGATCTTCCAGTAG-3' & & & \\
\hline Promotor $2 \mathrm{~F}$ & 5'-ACTTGTTCGGGAGAGAGAAGC-3' & PRO2 & 301 & 585960 \\
\hline Promotor2R & 5'-AGCTGTGTGACCTTGACCAAG-3' & & & \\
\hline Promotor $3 \mathrm{~F}$ & 5'-GGGAGATCTACTCCTGGACTC-3' & PRO3 & 300 & 606162 \\
\hline Promotor3R & 5'-AAATAGCGCTCGGTGGAGAAG-3' & & & \\
\hline Promotor4F & 5'-TCAGATTTAGGTGTGGGTGTG-3' & PRO4 & 291 & 596061 \\
\hline Promotor4R & 5'-CCCACCGACCAATCACCAGTC-3' & & & \\
\hline Promotor5F & 5'-CGCCCTTCCCGAGGTCTATTA-3' & PRO5 & 187 & 626364 \\
\hline Promotor5R & 5'-TCACGTGCGGAGGCTGAAACT-3' & & & \\
\hline
\end{tabular}


cal $P$ value of the genotype-wise TDT was 0.113 . The $P$ value in the allele-wise TDT was not less than the significant value. Therefore, the deviation of transmission of D17S579 was not convincingly significant. The calculated $P$ values we obtained for the markers THRA1 and D17S800 were greater than 0.05 in either the genotype-wise or allele-wise TDT. These observations suggested that none of the markers were associated with or in linkage disequilibrium to the disease locus. When the transmission of each allele was evaluated separately (allele-by-allele TDT), deviated transmissions of the $175 \mathrm{bp}$-allele of the THRA1 and the 121 bp-allele of the D17S579 were observed (Table 4). The $175 \mathrm{bp}$-allele was transmitted 3 times and not transmitted 11 times. The $\chi^{2}$ was 4.571 and the $P$ value was 0.033 . The $121 \mathrm{bp}$-allele was transmitted 12 times and not transmitted 3 times $\left(\chi^{2}=5.400, P=0.020\right)$. Although the $P$ values were not lower than the significant level when we applied the Bonferroni's correction on these values, we further ex-

Table 3. Extended transmission disequilibrium test

\begin{tabular}{|c|c|c|c|c|}
\hline & $\chi^{2}$ & $\begin{array}{l}\text { Degree of } \\
\text { freedom }\end{array}$ & $P$ value & $\begin{array}{l}\text { Empirical } \\
P \text { value }\end{array}$ \\
\hline \multicolumn{5}{|l|}{ THRA1 } \\
\hline Allele-wise TDT & 8.356 & 10 & 0.594 & 0.798 \\
\hline $\begin{array}{l}\text { Genotype-wise TDT } \\
\text { D17S579 }\end{array}$ & 28.435 & 21 & 0.129 & 0.379 \\
\hline Allele-wise TDT & 16.009 & 9 & 0.067 & 0.129 \\
\hline $\begin{array}{l}\text { Genotype-wise TDT } \\
\text { D17S800 }\end{array}$ & 37.451 & 23 & 0.030 & 0.113 \\
\hline Allele-wise TDT & 1.649 & 4 & 0.800 & 0.828 \\
\hline Genotype-wise TDT & 2.320 & 7 & 0.940 & 0.946 \\
\hline
\end{tabular}

$\chi^{2}$ and $P$ value were calculated by the ETDT program (Sham and Curtis 1995). Empirical $P$ value was calculated on the basis of 1000 simulation data by the MCETDT program (Zhao et al. 1999) plored the possibility that the $175 \mathrm{bp}$-allele of THRA1 or the $121 \mathrm{bp}$-allele of D17S579 was in linkage disequilibrium to particular nucleotide changes of the RARA gene. Using DHPLC, we screened the nucleotide changes in exons 1 to 9 of the RARA gene, which cover the entire coding sequence and the $5^{\prime}$ nontranslated region, in four patients who had the $175 \mathrm{bp}$-allele in a heterozygous form, in eight patients who had the $121 \mathrm{bp}$-allele in a heterozygous form, and in two patients who had both of the two alleles. No aberrant elution patterns were recorded, suggesting that no nucleotide change was in linkage disequilibrium to these two particular alleles.

The negative results of TDT do not exclude an association of the gene and the disease, because TDT shows positive results only when the nucleotide change and the disease alleles are in linkage disequilibrium. We thus screened the nucleotide changes in the $R A R A$ gene with an exon-byexon strategy. Exons 1 to 9 of the RARA gene of the eight probands who had family histories were amplified and directly sequenced. No mutations were found in the coding regions. A novel $1161 \mathrm{C}>\mathrm{T}$ mutation was found in exon 1 (the $5^{\prime}$ noncoding region) in one patient, whose mother had NSCLP (nucleotide number according to accession number AF088888). This mutation was not present in 50 control subjects. Because the patient inherited the $1161 \mathrm{C}>\mathrm{T}$ from his healthy father, this mutation was not considered to be responsible for the disease. We further screened nucleotide changes in the promoter region of the RARA gene in 48 probands with DHPLC. An aberrant pattern of peaks was observed in three individuals. Sequencing of these fragments with the aberrant chromatogram showed that all of them had one base deletion (thymine) in the 13-thymine tract $\left(\mathrm{T}_{13}\right)$ that starts at nucleotide 441 of the promoter sequence (nucleotide number is according to accession

Table 4. Allele-by-allele transmission disequilibrium test

\begin{tabular}{|c|c|c|c|c|c|c|c|c|c|c|c|}
\hline \multicolumn{12}{|l|}{ THRA1 } \\
\hline Allele & 153 & 165 & 167 & 169 & 171 & 173 & 175 & 177 & 179 & 181 & 183 \\
\hline $\begin{array}{l}\text { Passed } \\
\text { Not passed } \\
\chi^{2} \\
P \text { value }\end{array}$ & $\begin{array}{l}0 \\
1\end{array}$ & $\begin{array}{l}1 \\
1\end{array}$ & $\begin{array}{l}8 \\
6 \\
0.286 \\
0.593\end{array}$ & $\begin{array}{l}4 \\
3\end{array}$ & $\begin{array}{l}26 \\
19 \\
1.089 \\
0.297\end{array}$ & $\begin{array}{l}2 \\
2\end{array}$ & $\begin{array}{l}3 \\
11 \\
4.571 \\
0.033\end{array}$ & $\begin{array}{l}16 \\
17 \\
0.030 \\
0.862\end{array}$ & $\begin{array}{l}10 \\
11 \\
0.048 \\
0.827\end{array}$ & $\begin{array}{l}1 \\
1\end{array}$ & $\begin{array}{l}1 \\
0\end{array}$ \\
\hline \multicolumn{12}{|l|}{$\underline{\mathrm{D} 17 \mathrm{~S} 579}$} \\
\hline Allele & 111 & 113 & 115 & 117 & 119 & 121 & 123 & 125 & 127 & 129 & \\
\hline $\begin{array}{l}\text { Passed } \\
\text { Not passed } \\
\chi^{2} \\
P \text { value }\end{array}$ & $\begin{array}{l}8 \\
3 \\
2.273 \\
0.132\end{array}$ & $\begin{array}{l}8 \\
6 \\
0.286 \\
0.593\end{array}$ & $\begin{array}{l}1 \\
2\end{array}$ & $\begin{array}{l}1 \\
2\end{array}$ & $\begin{array}{l}3 \\
7 \\
1.600 \\
0.206\end{array}$ & $\begin{array}{l}12 \\
3 \\
5.400 \\
0.020\end{array}$ & $\begin{array}{l}20 \\
20 \\
0.000 \\
1.000\end{array}$ & $\begin{array}{l}20 \\
23 \\
0.209 \\
0.647\end{array}$ & $\begin{array}{l}5 \\
12 \\
2.882 \\
0.090\end{array}$ & $\begin{array}{l}2 \\
2\end{array}$ & \\
\hline \multicolumn{12}{|l|}{ D17S800 } \\
\hline Allele & 167 & 169 & 171 & 173 & 175 & 177 & & & & & \\
\hline $\begin{array}{l}\text { Passed } \\
\text { Not passed } \\
\chi^{2} \\
P \text { value }\end{array}$ & $\begin{array}{l}1 \\
1\end{array}$ & $\begin{array}{l}25 \\
19 \\
0.818 \\
0.366\end{array}$ & $\begin{array}{l}3 \\
5\end{array}$ & $\begin{array}{l}17 \\
23 \\
0.900 \\
0.343\end{array}$ & $\begin{array}{l}14 \\
12 \\
0.154 \\
0.695\end{array}$ & $\begin{array}{l}0 \\
3\end{array}$ & & & & & \\
\hline
\end{tabular}

$\overline{\chi^{2}}$ and $P$ value were calculated by the ETDT program (Sham and Curtis 1995). $\chi^{2}$ values are shown for alleles that appeared more than 10 times in heterozygous parents 
number AF088888). The allele frequency of this novel polymorphism was compared between the 48 patients and the 50 control subjects with direct sequencing. The frequencies of the $\mathrm{T}_{13}$ allele of the patients and controls were $52 \%$ and $55 \%$, respectively. There was no significant difference between these groups $\left(\chi^{2}=0.181, P=0.671\right)$.

\section{Discussion}

We carried out extended TDT with three multialleic microsatellite markers, THRA1, D17S579, and D17S800, which are located within $5 \mathrm{Mbp}$ of the $R A R A$ gene (distance according to Human Genome Map of NCBI (URL: www.ncbi.nlm.nih.gov). All calculated and empirical $P$ values obtained with the allele-wise TDT were more than 0.05 , providing no evidence of an association between the RARA gene and NSCLP. Our observation is in contrast to the previous report by Shaw et al. (1993). They showed that cleft-lip only patients had a higher frequency of the 125-bp allele of D17S579 when compared with patients with cleft lip and palate $\left(\chi^{2}=8.68, P=0.034\right)$. There was no difference in the allele frequency between 82 controls and all affected patients including 48 cleft-lip only patients and 22 patients with cleft lip and palate. The authors claimed that the data provided evidence of a relationship between the RARA gene and NSCLP. Using THRA1 as a marker, Maestri et al. (1997) performed TDT in 110 NSCLP and 50 cleft-palate only family trios. The global TDT $P$ value was less than 0.001 in NSCLP, suggesting the involvement of the $R A R A$ gene in the development of NSCLP. Eighty-seven percent of the families in their study were Caucasians and showed a higher odds ratio than in nonCaucasians. The data suggested that the RARA gene plays a significant role for developing NSCLP in Caucasians but not in other ethnic groups. The number of families studied in this paper is compatible with those of Shaw's and Maestri's reports and thought to be enough to replicate their results. Although it is difficult to estimate the precise power of the TDT in this study, if an inheritance of NSCLP were similar to a classical recessive disease, the power would be more than 0.9 (Sham and Curtis 1995). If, however, an inheritance of NSCLP between fit a common dominant or a common recessive model, the power would be less than 0.3 with our number of samples (Sham and Curtis 1995). From this study, we therefore can exclude the possibility of the RARA gene as a major susceptible gene for NSCLP but cannot totally exclude the possibility of the $R A R A$ gene as a gene with minor to moderate effects.

Although the global TDT with the three markers suggested that there was no involvement of the RARA gene in Japanese patients, we performed mutation screening in patients who had the 175-bp allele of THRA1 and/or the $121 \mathrm{bp}$ allele of D17S579, both of which showed a significantly deviated transmission when the allele was considered separately and Bonferroni's correction was not applied. The DHPLC analysis found no abnormal peaks, suggesting that no nucleotide changes existed in the coding and $5^{\prime}$ noncoding exons of these particular alleles of the $R A R A$ gene. In addition, mutation screening by direct sequencing of all coding exons in eight patients with family histories was carried out. Only one heterozygous mutation was found in the $5^{\prime}$ noncoding exon (exon1) of the RARA gene in one proband. However, this mutation was not segregated with the disease phenotype. We finally performed screening of nucleotide changes in the promoter region in all patients involved in this study. Three patients had one base deletion (thymine) in a heterozygous form. No association was found between this mutation and the disease in the case control study. Screening of the transcription factor binding motifs around this polymorphic site by TFSEARCH (http:// molsun1.cbrc.aist.go.jp/research/db/TFSEARCH.html) did not reveal binding motifs in the sense orientation. Although our results do not rule out the involvement of RA and RA receptor in the normal development of palate and lips, the data do not support the notion that variations of the $R A R A$ gene may affect the susceptibility to NSCLP.

An association between the RARA gene and NSCLP was first suggested by studying the Pst I RFLP of the gene in 117 Australian patients and 113 controls (Chenevix-Trench et al. 1992). Vintiner et al. (1993) studied 60 British patients with NSCLP and 60 control individuals, and could not confirm an association of this RFLP and the disease. The position of the Pst I RFLP site was not clear because the continuous genomic sequence of the RARA gene region was not available at this moment. We could not find possible Pst I RFLP sites in the regions we investigated in this study, suggesting that this RFLP is located in the intron of the RARA gene. Thus, the relationships between the RFLP and alleles of the three microsatellite markers are not clear. Because an association of the Pst I RFLP of the RARA gene and NSCLP could not be ruled out by our study, it is possible that this polymorphism is linked to an unknown disease-promoting polymorphism in a nearby gene.

Our study is the first attempt to investigate the association between the RARA gene and NSCLP in Japanese patients. We performed multialleic TDT with three $R A R A$ gene markers and searched nucleotide changes in the exons and promoter region of the $R A R A$ gene by direct sequencing and DHPLC methods. None of the results showed a significant association of the $R A R A$ gene with the disease. The nucleotide changes in the $R A R A$ gene do not seem to play an important role in determining susceptibility to NSCLP in the Japanese population.

Acknowledgments We thank Ms. Kumi Narita for excellent technical assistance. This work was supported by Grants-in-Aid for Scientific Research from the Ministry of Education, Culture, Sports, Science and Technology of Japan, and grants from the Ministry of Health, Labor, and Welfare of Japan.

\section{References}

Brand NJ, Petkovich M, Chambon P (1990) Characterization of a functional promoter for the human retinoic acid receptor-alpha (hRAR-alpha). Nucleic Acids Res 18:6799-6806 
Chenevix-Trench G, Jones K, Green AC, Duffy DL, Martin NG (1992) Cleft lip with or without cleft palate: associations with transforming growth factor alpha and retinoic acid receptor loci. Am J Hum Genet $51: 1377-1385$

Damm K, Heyman RA, Umesono K, Evans RM (1993) Functional inhibition of retinoic acid response by dominant negative retinoic acid receptor mutants. Proc Natl Acad Sci USA 90:29892993

Geelen JA (1979) Hypervitaminosis A induced teratogenesis. CRC Crit Rev Toxicol 6:351-375

Maestri NE, Beaty TH, Hetmanski J, Smith EA, McIntosh I, Wyszynski DF, Liang KY, Duffy DL, VanderKolk C (1997) Application of transmission disequilibrium tests to nonsyndromic oral clefts: including candidate genes and environmental exposures in the models. Am J Med Genet 73:337-344
Sham PC, Curtis D (1995) An extended transmission/disequilibrium test (TDT) for multi-allele marker loci. Ann Hum Genet 59:323-336 Shaw D, Ray A, Marazita M, Field L (1993) Further evidence of a relationship between the retinoic acid receptor alpha locus and nonsyndromic cleft lip with or without cleft palate $(\mathrm{CL}+/-\mathrm{P})$. Am J Hum Genet 53:1156-1157

Vintiner GM, Lo KK, Holder SE, Winter RM, Malcolm S (1993) Exclusion of candidate genes from a role in cleft lip with or without cleft palate: linkage and association studies. J Med Genet 30:773-778

Wyszynski DF, Beaty TH, Maestri NE (1996) Genetics of nonsyndromic oral clefts revisited. Cleft Palate Craniofac J 33:406417

Zhao JH, Sham PC, Curtis D (1999) A program for the monte carlo evaluation of significance of the extended transmission/disequilibrium test. Am J Hum Genet 64:1484-1485 